\title{
Activation of caspases and inhibition of ribosome biogenesis mediate antitumor activity of Chijongdan in A549 non-small lung cancer cells
}

\author{
Bo Geun Kim ${ }^{\dagger}$, Hee Young Kwon ${ }^{\dagger}$, Eun Jung Sohn ${ }^{\dagger}$, Sungmin Hwang, Oh sung Kwon and Sung-Hoon Kim*
}

\begin{abstract}
Background: Though herbal medicines have been used for cancer prevention and treatment, their scientific evidences still remain unclear so far. Thus, complementary and alternative medicine (CAM) project has been actively executed to reveal the scientific evidences in the USA and other countries. In the present study, we elucidated antitumor mechanism of Chijongdan, an oriental prescription of Rhus verniciflua, processed Panax ginseng, Persicaria tinctoria and Realgar, that has been traditionally applied for cancer treatment in Korea.
\end{abstract}

Methods: Chijongdan was prepared with extracts of Rhus verniciflua, processed Panax ginseng, Persicaria tinctoria and processed Realgar. The cytotoxicity of Chijongdan was measured by MTT colorimetric assay. Cell cycle analysis was performed by FACS. Western blot was performed to see the apoptosis related proteins.

Results: Chijongdan significantly exerted cytotoxicity in A549, H460 and H1299 non-small cell lung carcinoma (NSCLC) cells by MTT assay and also increased the number of ethidium homodimer positively stained cells in A549 NSCLC cells. Also, cell cycle analysis showed that Chijongdan increased sub-G1 population in a concentration dependent manner in A549 cells. In addition, Western blotting revealed that Chijongdan activated cleaved PARP, and caspase 9/3, while attenuated the expression of survival genes such as BCl-2, BCl-XL and survivin in A549 cells. Furthermore, Chijongdan suppressed the expression of ribosomal biogenesis related proteins such as upstream binding factor (UBF), Fibrillarin, NPM (B23) and Importin-7 (IPO7) and conversely pan-caspase inhibitor Z-VAD-FMK reversed the apoptotic ability of Chijongdan to cleave PARP and caspase 3 and attenuate the expression of UBF and Fibrillarin in A549 cells.

Conclusions: These findings suggest that Chijongdan induces apoptosis and inhibits ribosomal biogenesis proteins via caspase activation.

Keywords: Chijongdan, A549 non-small lung cancer cells, Caspase activation, Ribosomal biogenesis

\section{Background}

Though several therapeutic approaches such as surgery, chemotherapy, and radiotherapy have been effectively applied for cancer therapy, cancer is still one of intractable diseases all over the world [1,2]. Apoptosis, so called programmed cell death (PCD), is characterized by specific morphological features of cell shrinkage, nuclear condensation and fragmentation and membrane blebbing in the cells [3]. It usually includes two classical apoptotic

\footnotetext{
* Correspondence: sungkim7@khu.ac.kr

${ }^{\dagger}$ Equal contributors

College of Korean Medicine, Kyung Hee University, Hoegidong,

Dongdaemungu, Seoul 130-701, Republic of Korea
}

pathways such as the extrinsic death receptor pathway and intrinsic mitochondrial pathway. The extrinsic pathway is triggered by plasma membrane death receptor with its extracellular ligand Fas-L to activate caspase 8/3, while intrinsic pathway releases cytochrome c to form apoptosome to activate caspase $9 / 3$ in the cells [4]. Thus, recently apoptosis is one of important targets in cancer therapy $[4,5]$ and also some herbal medicines are attractive for cancer prevention and therapy with little toxicity or combination supplement with anticancer agents [6-8]. 
Ribosome biogenesis is the process of making ribosomes in the cytoplasm and nucleolus to coordinate the synthesis and processing of rRNAs, and make the assembly of those rRNAs with the ribosomal proteins to maintain cell homeostasis and survival [9]. Also, there are accumulating evidences that altered ribosomal proteins $[10,11]$ and nuclear proteins [12-14] such as Twist, upstream binding factor (UBF), Fibrillarin, nucleophosmin (NPM, B23), exportin1 (XPO1) and importin7 (IPO7) are involved in cancer progression [15]. In contrast, some ribosomal proteins such as L13a, rp22 and rp23 were reported to function as cell cycle checkpoints and compose a new family of cell proliferation regulators [9].

Chijongdan, consisting of Rhus verniciflua, processed Panax ginseng, Persicaria tinctoria and Realgar, has been traditionally applied for cancer treatment in Korea. Nevertheless, the scientific evidence of Chijongdan is still lacking except one clinical case report [16] that Chijongdan retarded tumor size of the patient with colorectal cancer without side effect until now. Thus, in the present study, the underlying antitumor mechanism of Chijongdan using minimum dose $(1 \%)$ of Realgar to reduce its toxicity and enhance synergistic antitumor activity with other constituent herbs was elucidated in association with apoptosis and ribosomal proteins mainly in A549 non-small lung carcinoma cells.

\section{Methods}

\section{Preparation of Chijongdan}

Chijongdan, consisting of three herbs and one mineral such as Rhus verniciflua, processed Panax ginseng, Persicaria tinctoria and processed Realgar, was prepared in 95\% ethanol. Briefly, three herbs and one mineral were obtained from Korean Medical Hospital of Kyunghee University (Seoul, Korea) and kindly authenticated by Dr. Nam-In Baek (Department of Oriental Herbal Materials, Kyunghee University). Its four constituents (Rhus verniciflua, Panax ginseng, Persicaria tinctoria and processed Realgar), which were stored at Cancer Prevention Material Development Research Center (CPMDRC, Korea), and soaked with ethanol ( 2 liters $\times 3$ changes) at room temperature for 7 days. The extract was filtered through filter paper (pore size, $3 \mu \mathrm{m}$ ), evaporated (Rotary Evaporator, model NE-1, Japan), and lyophilized (Freeze Dryer, Lioalfa-6, Telstar, Terrassa, Spain) to produce dry powder. Then, the extracts of Chijongdan were mixed together with the ratio of Chijongdan constituents (Rhus verniciflua, Panax ginseng, Persicaria tinctoria, Realgar $=60: 30: 9: 1 \%)$.

\section{Cell culture}

A549, H460, and H1299 cells were obtained from American Type Culture Collection (ATCC). The cells were cultured in RPMI 1640 (Welgene, Daegu, Korea) supplemented with 10\% fetal bovine serum (FBS) (Welgene,
Daegu, Korea) and $1 \%$ antibiotics at $37^{\circ} \mathrm{C}$ in a humidified $5 \% \mathrm{CO}_{2}$ atmosphere.

\section{Cytotoxicity assay}

The cytotoxicity of Chijongdan and its four constituents was measured in A549, H460 and H1299 lung adenocarcinoma cells by MTT colorimetric assay. The cells were seeded onto 96-well microplates at a density of $1 \times 10^{4}$ cells per well and treated with various concentrations of Chijongdan, Rhus verniciflua, processed Panax ginseng, Persicaria tinctoria and Realgar for $24 \sim 48 \mathrm{~h}$. MTT working solution $(5 \mathrm{mg} / \mathrm{ml}$ in PBS) was added to each well and incubated at $37^{\circ} \mathrm{C}$ for $2 \mathrm{~h}$. The optical density (OD) was then measured at $570 \mathrm{~nm}$ using a microplate reader (Sunrise, TECAN, Männedorf, Switzerland). Cell viability was calculated as a percentage of viable cells in Chijongdan, Rhus verniciflua, processed Panax ginseng, Persicaria tinctoria and Realgar-treated group versus untreated control by the following equation.

$$
\begin{aligned}
\text { Cell viability }(\%)= & {[\text { OD }(\text { Chijongdan or each constituent })} \\
& - \text { OD }(\text { Blank })] /[\text { OD }(\text { Control }) \\
& - \text { OD }(\text { Blank })] \times 100 .
\end{aligned}
$$

\section{Ethidium homodimer assay}

To measure cell death, we used DAPI and ethidium homodimer dye following the manufactures' instructions (Molecular Probes). In brief, A549 cells were treated with 100 and $200 \mu \mathrm{g} / \mathrm{ml}$ of Chijongdan for $24 \mathrm{~h}$. After incubation, cells were fixed in $4 \%$ methanolfree formaldehyde solution, stained with the $5 \mu \mathrm{M}$ ethidium homodimer and then incubated at $37^{\circ} \mathrm{C}$ for $30 \mathrm{~min}$ in the dark. Then the cells were mounted with mounting medium containing DAPI and then visualized under a Fluoview FV10i confocal microscope (OLYMPUS, Tokyo, Japan).

\section{Cell cycle analysis}

A549 cells treated with Chijongdan (50, 100, 200 and $400 \mu \mathrm{g} / \mathrm{ml}$ ) for $24 \mathrm{~h}$ were fixed in $75 \%$ ethanol at $-20^{\circ} \mathrm{C}$, resuspended in PBS containing RNase A (1 mg/ml), and incubated for $1 \mathrm{~h}$ at $37^{\circ} \mathrm{C}$. The fixed cells were stained with propidium iodide $(50 \mu \mathrm{g} / \mathrm{ml})$ for $30 \mathrm{~min}$ at room temperature in dark. The DNA contents of the stained cells were analyzed using CellQuest Software with the FACSCalibur flow cytometry (Becton Dickinson, Franklin Lakes, NJ).

\section{Western blotting}

Whole cell lysates from the cells exposed to Chijongdan $(25,50,100$ and $200 \mu \mathrm{g} / \mathrm{ml})$ for $24 \mathrm{~h}$ were prepared using RIPA buffer (50 mM Tris- $\mathrm{HCl}, \mathrm{pH}$ 7.5, $150 \mathrm{mM}$ 
sodium chloride, $1 \%$ Triton X-100, 0.1\% SDS, $2 \mathrm{mM}$ EDTA, $0.5 \%$ sodium deoxycholate). The protein contents in the supernatants were measured by using a Bio-Rad DC protein assay kit II (Bio-Rad, Hercules, CA), separated on 4-12\% NuPAGE Bis-Tris gels (Invitrogen, Carlsbad, CA) and electro-transferred onto a
Hybond ECL transfer membrane (GE Health Are BioScience, Piscataway, NJ). The membranes were blocked with 5\% nonfat dry milk and immunoblotted with caspase-3, caspase-9, PARP, Bcl-2, Bcl- $\mathrm{x}_{\mathrm{L}}$, survivin, UBF, Fibrillarin, NPM (B23), IPO7 or $\beta$-actin (Cell signaling, Danvers, MA) antibodies.
(A)

A549 cells Chijongdan
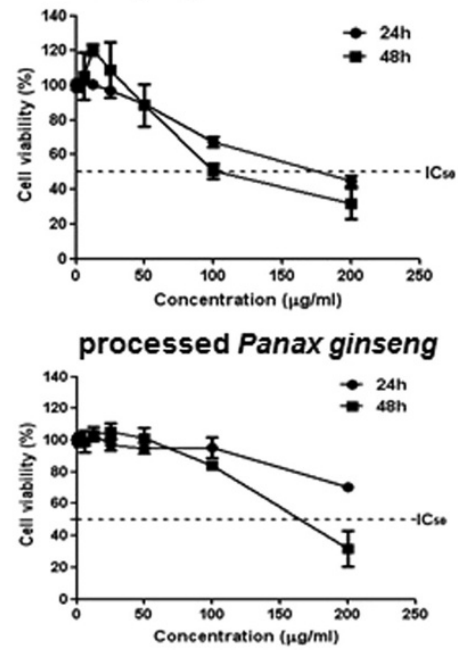

Rhus verniciflua

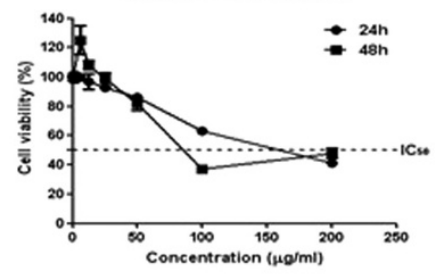

Persicaria tinctoria

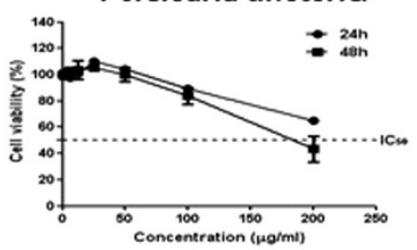

Realgar

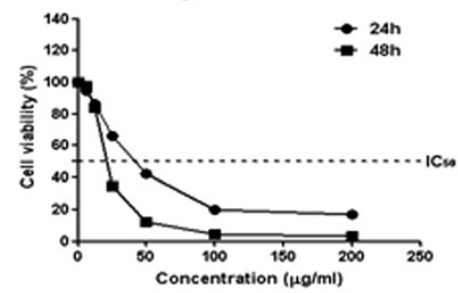

(B) H460 cells Chijongdan

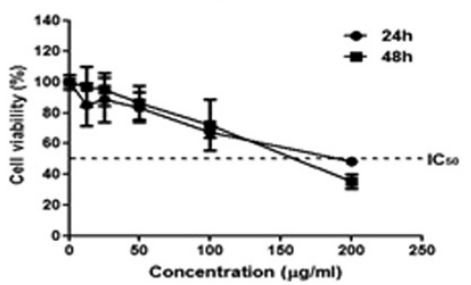

(C)

H1299 cells Chijongdan

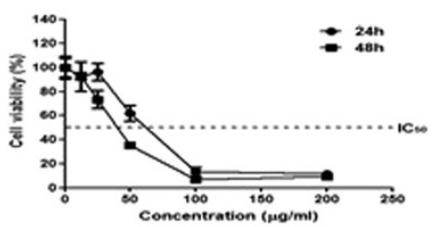

(D)

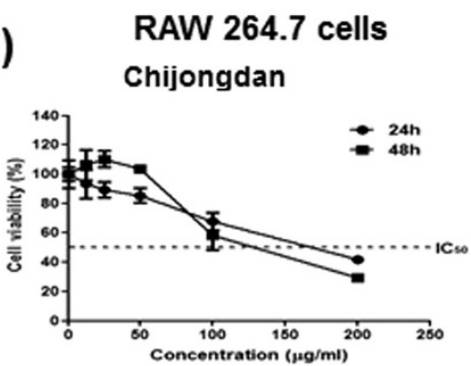

Figure 1 Cytotoxicity of Chijongdan and its constituents in non-small cell lung carcinoma cells. A549, H460 and H1299 cells were exposed to Chijongdan for 24 or 48 h. Then MTT assay was performed as shown in Methods. Effect of Chijongdan and the constituents on cytotoxicity in A549 (A), H460 (B), H1299 (C) and RAW264.7 cells (D). All data were expressed as means \pm standard deviation (SD). 


\section{Statistical analyses}

Statistical analysis of the data was conducted using Sigmaplot version 12 software (Systat Software Inc., San Jose, CA). All data were expressed as means \pm standard deviation (SD). One-way ANOVA was used for comparison of multiple groups. Student $t$-test was used for comparison of two groups. Statistical difference was set at $p$ values of $<0.05$ between control and Chijongdan-treated groups.

\section{Results}

Chijongdan and its constituents exerted the cytotoxicity against human non-small cell lung cancer cells

To evaluate the cytotoxic effect of Chijongdan and its constituents in human non-small cell lung carcinoma cells (NSCLC), we conducted MTT assay. A549, H460 and H1299 cells were treated with various concentrations (0, $6.25,12.5,25,50,100$ or $200 \mu \mathrm{g} / \mathrm{ml}$ ) of Chijongdan and its constituents such as Rhus verniciflua, processed Panax ginseng, Persicaria tinctoria and processed Realgar for $24 \mathrm{~h}$ and $48 \mathrm{~h}$. Chijongdan significantly decreased the viability of A549, H460 and H1299 cells (Figure 1A, B, C). However, the cytotoxicity of Chijongdan was weaker in RAW264.7 macrophage cells compared to H1299 cells (Figure 1D), but not significantly for other NSCLCs, implying somewhat cytotoxicity in normal cells. Realgar was more cytotoxic in A549 cells than other constituent herbs such as Rhus verniciflua, processed Panax ginseng and Persicaria tinctoria (Figure 1A).

\section{Chijongdan induced apoptotic morphology in A549 cells} Morphological changes in Chijongdan treated A549 cells were observed under inverted microscopy. As shown in Figure $2 \mathrm{~A}$, the cells treated with $0,50,100$ or $200 \mu \mathrm{g} / \mathrm{ml}$ of Chijongdan for $24 \mathrm{~h}$ exhibited apoptotic features such as apoptotic bodies and cell shrinkage.

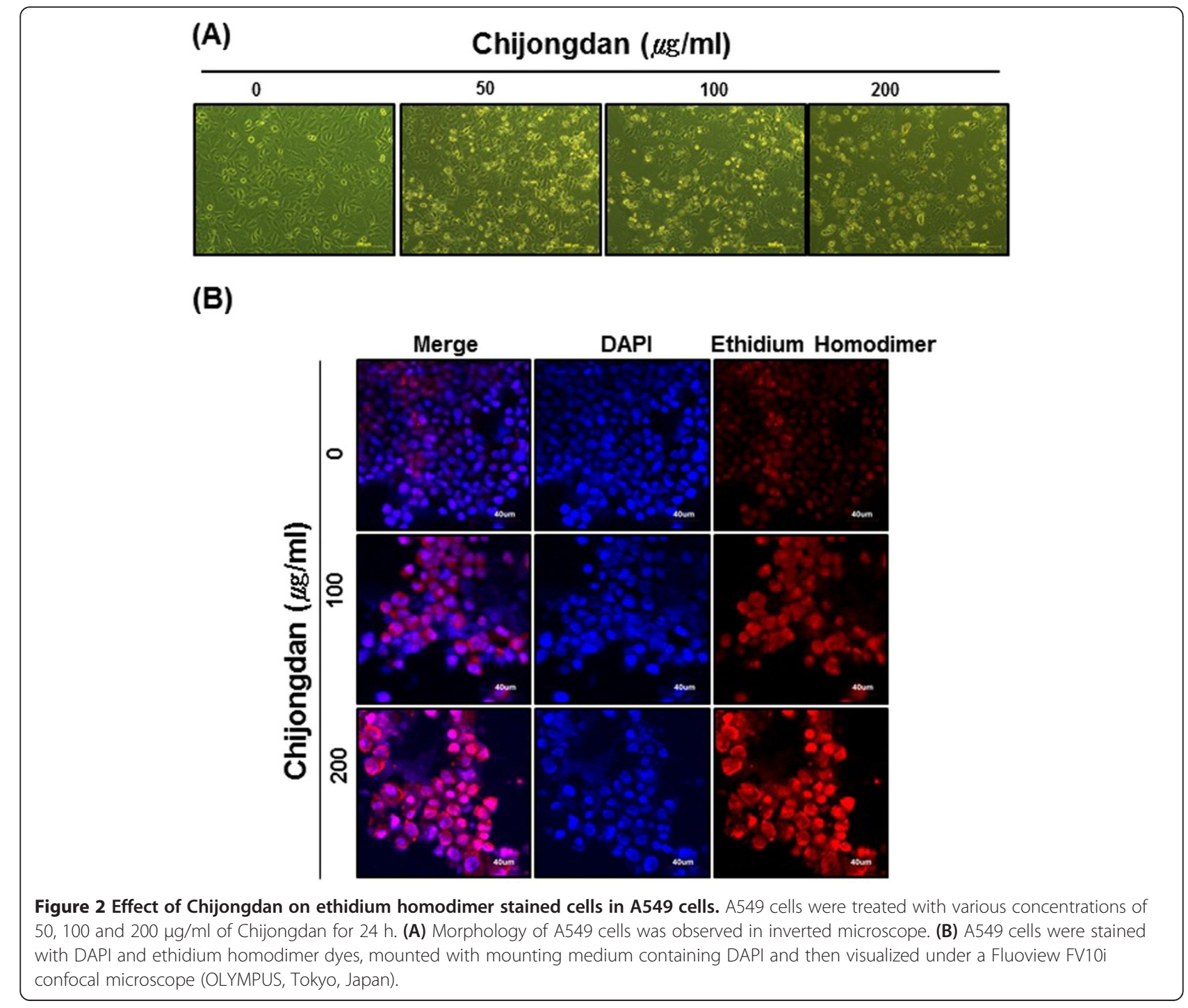


Chijongdan increased ethidium homodimer positively stained cells in A549 cells

Ethidium homodimer dye staining was performed to detect cell death. We observed apoptotic bodies in
Chijongdan treated A549 cells in a dose dependent manner, indicating apoptotic feature, while intact morphology was shown in untreated control (Figure 2B).

(A)
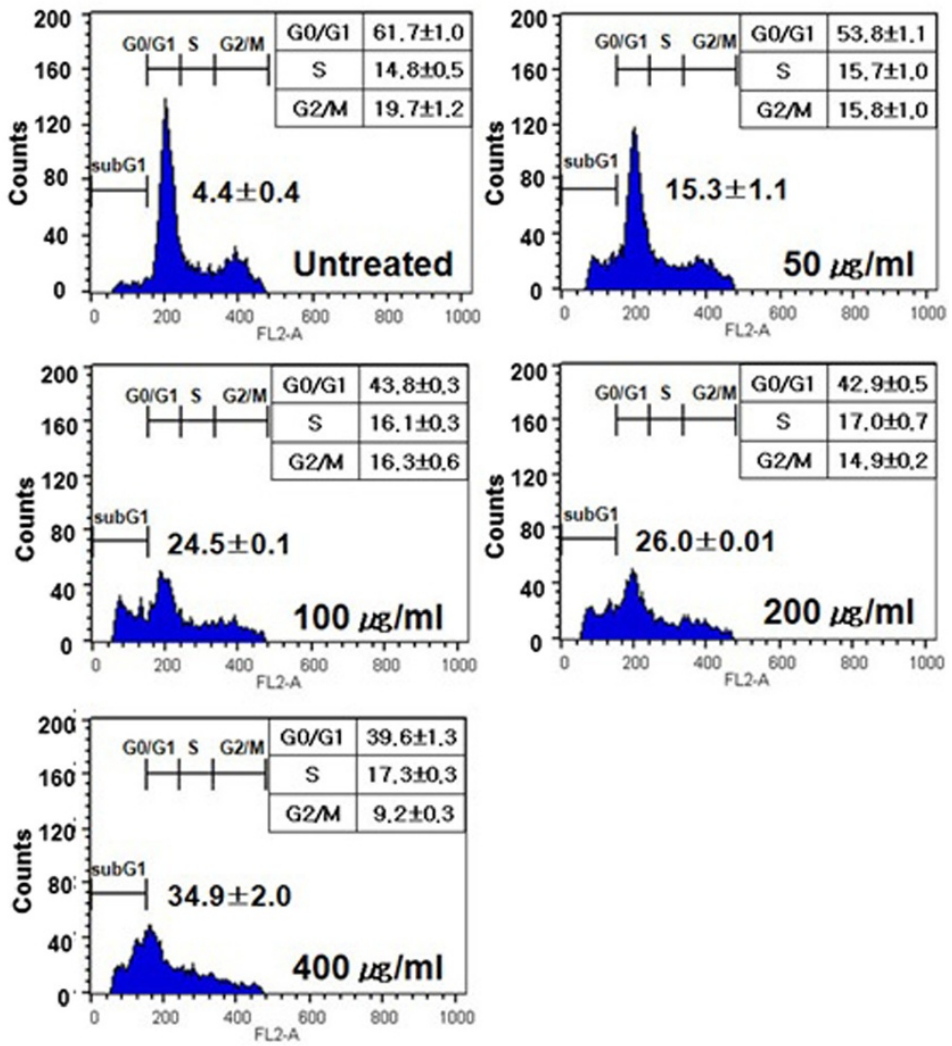

(B)

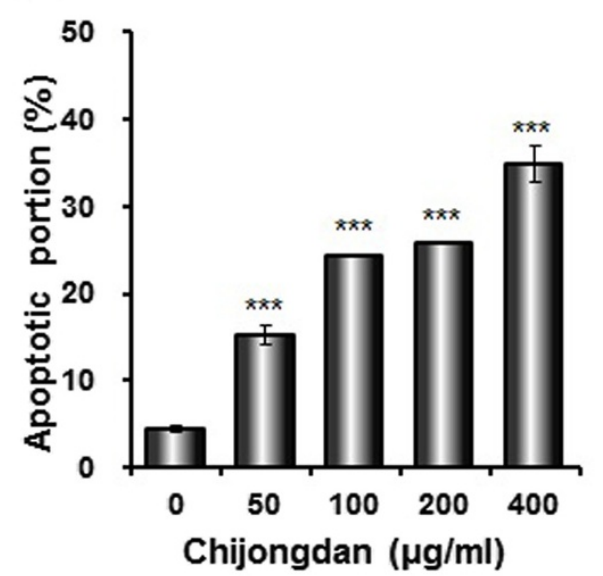

Figure 3 Effect of Chijongdan on sub G1 population in A549 cells. A549 cells were treated with 50, 100, 200 and $400 \mu \mathrm{g} / \mathrm{ml}$ of Chijongdan for $24 \mathrm{~h}$ and stained with propidium iodide $(50 \mathrm{\mu g} / \mathrm{ml})$ for $30 \mathrm{~min}$ at room temperature in dark. (A) The DNA contents of the stained cells were analyzed by the FACSCalibur flow cytometry. (B) Bar graphs represent percentages of apoptotic portion. All data were expressed as means \pm standard deviation (SD). ${ }^{* *} \mathrm{p}<0.001$ vs. untreated control. 
Chijongdan significantly increased the sub-G1 portion in A549 cells

To investigate the effect of Chijongdan on cell cycle phase distribution, A549 cells were treated with various concentrations $(0,50,100,200$ or $400 \mu \mathrm{g} / \mathrm{ml})$ of Chijongdan. As shown in Figure 3A and 3B, Chijongdan significantly increased sub-G1 phase proportion in a dose dependent manner.

\section{Chijongdan regulated apoptosis related proteins in} A549 cells

To confirm whether the cytotoxic effect of Chijongdan in A549 is associated with apoptosis, we performed Western blotting. A549 cells were treated with 25, 50, 100 and $200 \mu \mathrm{g} / \mathrm{ml}$ of Chijongdan for $24 \mathrm{~h}$. The cell lysates were prepared and subjected to Western blotting for PARP, procasepase-3, $-9, \mathrm{Bcl}-\mathrm{x}_{\mathrm{L}}, \mathrm{Bcl}-2$, and survivin. Consistent with previous data, anti-apoptotic proteins such as Bcl- $\mathrm{x}_{\mathrm{L}}, \mathrm{Bcl}-2$, and survivin were downregulated by Chijongdan in a dose dependent manner, while proapoptotic protein such as caspase-3, -9 and PARP were cleaved in A549 cells (Figure 4A,B).

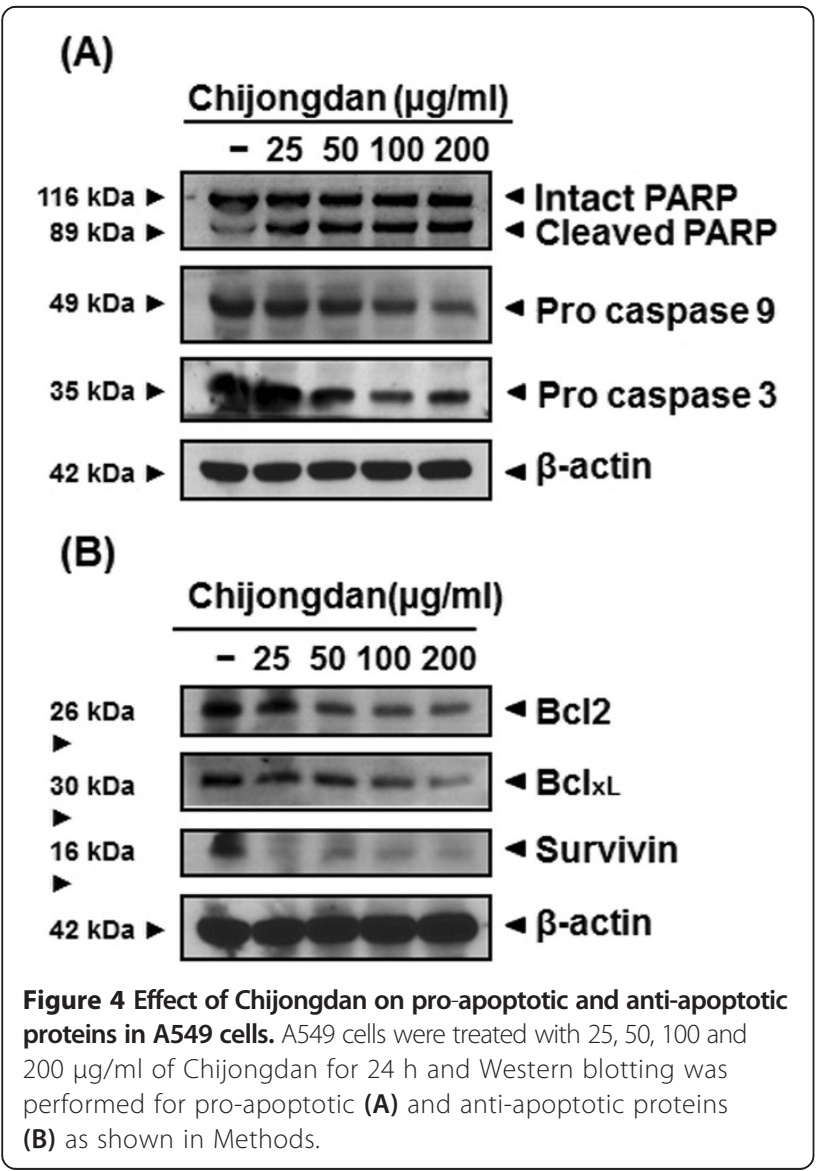

Effect of Chijongdan on apoptotic and ribosome biogenesis related proteins was reversed by pancaspase inhibitor Z-VAD-FMK in A549 cells

It was well demonstrated that ribosome production was enhanced in cancer cells and that ribosome biogenesis played a crucial role in tumor progression [17]. To confirm that Chijongdan can regulate the ribosome biogenesis related proteins, we conducted Western blotting. As shown in Figure 5A, Chijongdan down-regulated UBF, Fibrillarin, NPM and IPO7 in a dose dependent fashion. Conversely, the effects of Chijongdan on ribosome biogenesis and apoptosis were reversed by pancaspase inhibitor Z-VAD-FMK (Figure 5B), indicating that Chijongdan induces apoptosis and inhibits ribosomal biogenesis proteins via caspase activation.

\section{Discussion}

Lung cancer is the most common cause of cancer death worldwide [18]. Among lung cancers, $80 \%$ are classified as non-small cell lung cancer (NSCLC) and 20\% are small cell lung cancer (SCLC). Though recently advanced computed tomography (CT) scanning made possible detection of NSCLCs at earlier stages [19], over

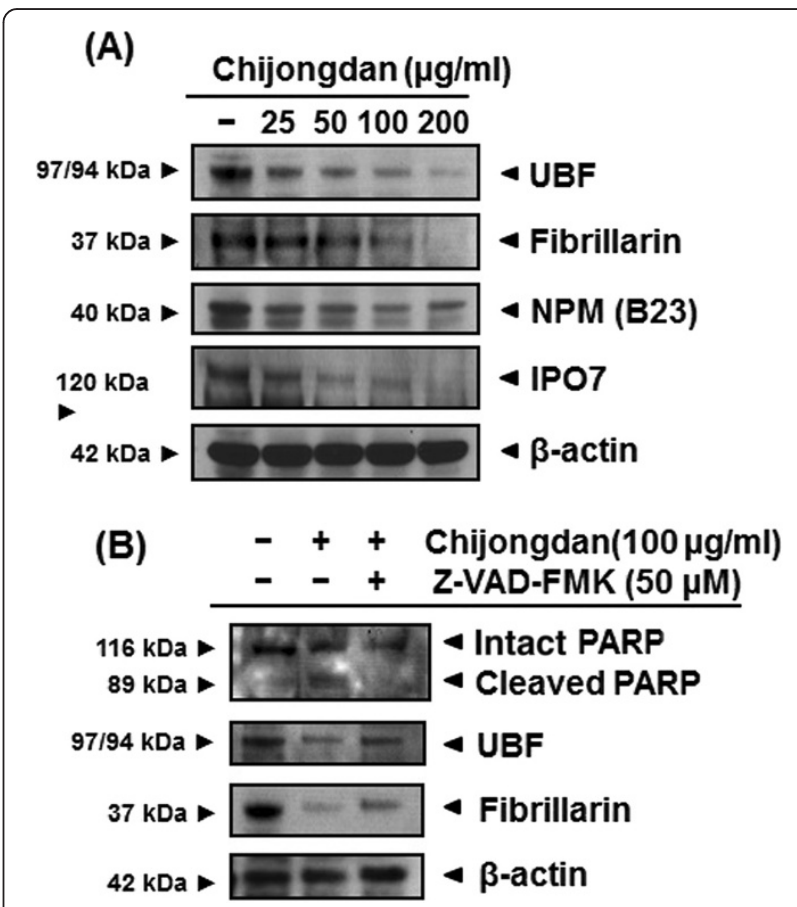

Figure 5 Effect of Chijongdan on apoptotic and ribosome biogenesis related proteins was reversed by pancaspase inhibitor Z-VAD-FMK in A549 cells. (A) Effect of Chijongdan on ribosomal biogenesis related proteins in A549 cells. (B) Effect of pan-caspase inhibitor Z-VAD-FMK on the ability of Chijongdan to inhibit ribosomal biogenesis and induce apoptosis in A549 cells. A549 cells were treated with $100 \mu \mathrm{g} / \mathrm{ml}$ of Chijongdan and/or pan-caspase inhibitor Z-VAD-FMK for $24 \mathrm{~h}$ and Western blotting was performed for UBF, Fibrillarin and PARP as shown in Methods. 
$70 \%$ of lung cancers are still loco-regionally advanced or metastatic at the time of diagnosis [20]. Cell proliferation needs to duplicate their own structural and functional components [21] via increased protein synthesis which, in turn, followed by an up-regulation of the ribosome biogenesis rate [21-23].

Herbal mixture Chijongdan has been traditionally used for cancer therapy without clear scientific evidences. Among constituents of Chijongdan, Rhus verniciflua was known to have antitumor activity in A549 lung cancer [24], MCF-7 breast cancer [25], lymphoma [26], osteosarcoma [27] and renal cancer [28] and also processed Panax ginseng was reported to exert antitumor effect in AGS gastric cancer. Also, Persicaria tinctoria contained tyrosine kinase inhibitory compounds [29] and Realgar was reported to be too cytotoxic and apoptotic in chronic lymphocytic leukemia or cervical cell lines [30,31]. Here, based on previous antitumor evidences of its constituents, antitumor activity of Chijongdan was hypothesized. Thus, we investigated antitumor mechanism of Chijongdan in association with apoptosis and ribosomal proteins in nonsmall lung carcinoma cells. Here we found that Chijongdan and its constituents significantly exerted cytotoxicity in A549, H460 and H1299 NSCLC cells, showed morphologic changes such as apoptotic bodies cell shrinkage in a dose dependent manner and increased the number of ethidium homodimer positively stained cells in A549 cells, indicating the cytotoxicity of Chijongdan was due to apoptosis induction in A549 cells. Consistently, cell cycle analysis showed that Chijongdan increased sub-G1 population and also cleaved PARP, activated caspase9/3, and attenuated the expressed of survival genes such as Bcl-2, Bcl- $\mathrm{x}_{\mathrm{L}}$ and survivin in A549 cells, implying Chijongdan induces apoptosis and suppresses survival genes. Furthermore, Chijongdan repressed the expression of ribosome biogenesis related proteins such as UBF, Fibrillarin, NPM, and IPO7, indicating that Chijongdan can inhibit the rDNA transcription or processing of rRNA during cancer progression of A549 cells. Similarly, melatonin suppressed 45S preribosomal RNA and UBF and enhanced the antitumor activity of puromycin in MDA-MB 231 breast cancer cells [32]. Interestingly, the antitumor ability of Chijongdan to cleave PARP and caspase 3 and inhibit the expression of UBF and Fibrillarin was blocked by pancaspase inhibitor Z-VAD-FMK in A549 cells, demonstrating that caspase activation mediates the inhibition of ribosomal biogenesis by Chijongdan in A549 cells.

\section{Conclusions}

Taken together, these findings suggest that Chijongdan induces apoptosis and inhibits ribosomal biogenesis proteins via caspase activation in A549 non-small cell lung carcinoma cells, though it still needs further research including in vivo efficacy and safety and pharmacodynamic studies with Chijongdan and its constituents in the future.

\section{Competing interests}

The authors declare no competing interests.

\section{Authors' contribution}

BGK, EJS and SHK designed the experiments. HYK, BGK, SMH, OSK and EJS performed the experiments and analysed data. EJS and SHK wrote manuscript. All authors read and approved the final manuscript.

\section{Acknowledgement}

This work was supported by the Korea Science and Engineering Foundation (KOSEF) grant funded by the Korea government (MEST) (No. 2012-0005755).

Received: 27 December 2013 Accepted: 4 August 2014

Published: 27 October 2014

\section{References}

1. Murovic JA, Chang SD: Literature review of various treatment plans and outcomes for brain metastases from colorectal cancer. World Neurosurg 2013, 79(3-4):435-436.

2. Ochoa R, Sudhindra A, Garcia-Buitrago M, Romilly AP, Cortes J, Gomez H, Rocha Lima CM, Silva O: Small-cell cancer of the breast: what is the optimal treatment? A report and review of outcomes. Clin Breast Cancer 2012, 12(4):287-292.

3. Portt L, Norman G, Clapp C, Greenwood M, Greenwood MT: Anti-apoptosis and cell survival: a review. Biochim Biophys Acta 2011, 1813(1):238-259.

4. Ouyang L, Shi Z, Zhao S, Wang FT, Zhou TT, Liu B, Bao JK: Programmed cell death pathways in cancer: a review of apoptosis, autophagy and programmed necrosis. Cell Prolif 2012, 45(6):487-498.

5. Kleinberg L, Davidson B: Cell survival and apoptosis-related molecules in cancer cells in effusions: a comprehensive review. Diagn Cytopathol 2009, 37(8):613-624

6. Arslan D, Tural D, Akar E: Herbal administration and interaction of cancer treatment. J Palliat Med 2013, 16(11):1466-1476.

7. Jiang C, Lee HJ, Li GX, Guo J, Malewicz B, Zhao Y, Lee EO, Lee HJ, Lee JH, Kim MS, Kim SH, Lu J: Potent antiandrogen and androgen receptor activities of an Angelica gigas-containing herbal formulation: identification of decursin as a novel and active compound with implications for prevention and treatment of prostate cancer. Cancer Res 2006, 66(1):453-463.

8. Wang CZ, Calway T, Yuan CS: Herbal medicines as adjuvants for cancer therapeutics. Am J Chin Med 2012, 40(4):657-669.

9. Chen FW, loannou YA: Ribosomal proteins in cell proliferation and apoptosis. Int Rev Immunol 1999, 18(5-6):429-448.

10. Dai MS, Lu H: Crosstalk between c-Myc and ribosome in ribosomal biogenesis and cancer. J Cell Biochem 2008, 105(3):670-677.

11. Jang CY, Kim HD, Kim J: Ribosomal protein S3 interacts with TRADD to induce apoptosis through caspase dependent JNK activation. Biochem Biophys Res Commun 2012, 421(3):474-478.

12. Soldani C, Bottone MG, Pellicciari C, Scovassi Al: Nucleolus disassembly in mitosis and apoptosis: dynamic redistribution of phosphorylated-c-Myc, Fibrillarin and Ki-67. Eur J Histochem 2006, 50(4):273-280.

13. Paik JC, Wang B, Liu K, Lue JK, Lin WC: Regulation of E2F1-induced apoptosis by the nucleolar protein RRP1B. J Biol Chem 2010, 285(9):6348-6363.

14. Naora $\mathrm{H}$ : Involvement of ribosomal proteins in regulating cell growth and apoptosis: translational modulation or recruitment for extraribosomal activity? Immunol Cell Biol 1999, 77(3):197-205.

15. Golomb L, Bublik DR, Wilder S, Nevo R, Kiss V, Grabusic K, Volarevic S, Oren M: Importin 7 and exportin 1 link c-Myc and p53 to regulation of ribosomal biogenesis. Molecular cell 2012, 45(2):222-232.

16. Kim BGPS: Treatment of Rhus vernifciflua STOKES decoction to colorectal cancer patient (stage IV): single case report. J Korea Tradit Oncol 2010, 5(1):117-119.

17. Belin S, Beghin A, Solano-Gonzalez E, Bezin L, Brunet-Manquat S, Textoris J, Prats AC, Mertani HC, Dumontet C, Diaz JJ: Dysregulation of ribosome biogenesis and translational capacity is associated with tumor progression of human breast cancer cells. PLoS One 2009, 4(9):e7147.

18. Ferlay J, Parkin DM, Steliarova-Foucher E: Estimates of cancer incidence and mortality in Europe in 2008. Eur J Cancer 2010, 46(4):765-781. 
19. Aberle DR, Adams AM, Berg CD, Black WC, Clapp JD, Fagerstrom RM, Gareen IF, Gatsonis C, Marcus PM, Sicks JD: Reduced lung-cancer mortality with low-dose computed tomographic screening. N Engl J Med 2011, 365(5):395-409.

20. Rothschild SI: Epigenetic Therapy in Lung Cancer - Role of microRNAs. Front Oncol 2013, 3:158.

21. Thomas G: An encore for ribosome biogenesis in the control of cell proliferation. Nat Cell Biol 2000, 2(5):E71-E72.

22. Conlon I, Raff M: Size control in animal development. Cell 1999, 96(2):235-244.

23. Schmidt EV: The role of c-myc in cellular growth control. Oncogene 1999, 18(19):2988-2996

24. Cheon SH, Kim KS, Kim S, Jung HS, Choi WC, Eo WK: Efficacy and safety of Rhus verniciflua stokes extracts in patients with previously treated advanced non-small cell lung cancer. Forschende Komplementarmedizin 2011, 18(2):77-83.

25. Lee JO, Moon JW, Lee SK, Kim SM, Kim N, Ko SG, Kim HS, Park SH: Rhus verniciflua Stokes (RVS) extract modulates survival of MCF-7 Breast Cancer Cells through the Modulation of AMPK-Pathway. Biol Pharm Bull 2014, 37(4):794-801.

26. Lee JC, Lee KY, Kim J, Na CS, Jung NC, Chung GH, Jang YS: Extract from Rhus verniciflua Stokes is capable of inhibiting the growth of human lymphoma cells. Food Chem Toxicol 2004, 42(9):1383-1388.

27. Jang HS, Kook SH, Son YO, Kim JG, Jeon YM, Jang YS, Choi KC, Kim J, Han SK, Lee KY, Park BK, Cho NP, Lee JC: Flavonoids purified from Rhus verniciflua Stokes actively inhibit cell growth and induce apoptosis in human osteosarcoma cells. Biochimica et biophysica acta 2005, 1726(3):309-316.

28. Lee JH, Lee HJ, Lee HJ, Choi WC, Yoon SW, Ko SG, Ahn KS, Choi SH, Ahn KS, Lieske JC, Kim SH: Rhus verniciflua Stokes prevents cisplatin-induced cytotoxicity and reactive oxygen species production in MDCK-I renal cells and intact mice. Phytomedicine 2009, 16(2-3):188-197.

29. Woo YMKA, Kim JY, Lee CH: Tyrosine inhibitory compounds isolated from Persicaria tinctoria flower. J Appl Biol Chem 2011, 54(1):47-50.

30. Liu X, Li X, Wang L, Lv X, Chen N, Li P, Lu K, Wang X: Realgar induces apoptosis in the chronic lymphocytic leukemia cell line MEC1. Mol Med Rep 2013, 8(6):1866-1870.

31. Cheng YX, Liu R, Wang Q, Li BS, Xu XX, Hu M, Chen L, Fu Q, Pu DM, Hong L: Realgar-induced apoptosis of cervical cancer cell line Siha via cytochrome c release and caspase-3 and caspase-9 activation. Chin J Integr Med 2012, 18(5):359-365.

32. Jung JH, Sohn EJ, Shin EA, Lee D, Kim B, Jung DB, Kim JH, Yun M, Lee HJ, Park YK, Kim SH: Melatonin Suppresses the Expression of 45S

Preribosomal RNA and Upstream Binding Factor and Enhances the Antitumor Activity of Puromycin in MDA-MB-231 Breast Cancer Cells. Evid Based Complement Alternat Med: ECAM 2013, 2013:879746.

doi:10.1186/1472-6882-14-420

Cite this article as: Kim et al:: Activation of caspases and inhibition of ribosome biogenesis mediate antitumor activity of Chijongdan in A549 non-small lung cancer cells. BMC Complementary and Alternative Medicine 2014 14:420.

\section{Submit your next manuscript to BioMed Central and take full advantage of:}

- Convenient online submission

- Thorough peer review

- No space constraints or color figure charges

- Immediate publication on acceptance

- Inclusion in PubMed, CAS, Scopus and Google Scholar

- Research which is freely available for redistribution 